\title{
Revised the Stigma of Ignorance in the Village: Village Financial Accountability Model Through The Village Partner Application in Wonosobo District
}

\author{
Akhmad Habibullah ${ }^{1}$, Sakir $^{2}$ \\ \{abizurkati@gmail.com $\left.{ }^{1}\right\}$ \\ Universitas Muhammadiyah Yogyakarta, Indonesia ${ }^{1}$ \\ Universitas Muhammadiyah Yogyakarta, Indonesia ${ }^{2}$
}

\begin{abstract}
The implementation of "good governance" was implemented by the central government also brought a very strong wave to the lowest government in the village. One good governance indicator is accountability. Therefore, this paper aims to test and present accountability data in Indonesia, especially the accountability of the village financial system. Many tools or instruments can be used to view the accountability of government programs, one of which is application-based. There is a stigma that assumes the village is less reliable in the use of the budget, let alone in the use of technology. However, this does not apply in Wonosobo District. The village serves as a strategic development object that is expected to make people's lives at the rural level possible. In Wonosobo District, accountability for village accountability is already application-based, ie "Mitra Desa" application, as many as 236 villages in Wonosobo District have adopted an application to facilitate villages in managing their financial records from planning, budgeting and reporting. This is because previously the village financial management is still not good. From the results of this study, it can be concluded that there is a fairly good improvement in management and financial accountability in the village in Wonosobo District. This is also felt by the people and government of Wonosobo District because the activities of control and reporting of funds are much more effective and efficient.
\end{abstract}

Keywords: Accountability, Village Financing, Village Partner

\section{Introduction}

Law Number 6 the Year 2014 (hereinafter referred to as the Village Law) provides a great opportunity for the village to prosper its citizens. The village appointed directly become the actors of development through recognition of its existence, the granting of authority as well as the fulfillment of fiscal rights and obligations. Space becomes an opportunity as well as a challenge for the village to become an active actor in development. The Village Law which sees villages as community units and village administrations opens opportunities for wider community participation to engage, influence and become a direct part of development [1].

There is a stigma that is always inherent when we speak of village problems even more so in Indonesia, stodgy, conservative, ancient, and even stupid, such an assumption is inherent today. Especially when we talk about the existing financial management problems in the 
village at present which reaches 800 million to 1.4 billion per year per village. Many of the villages considered weak in financial management are even considered unable to carry out their duties and obligations on such a large amount of funds. Yet all of these allegations, perceptions, and assumptions do not apply in villages in Wonosobo regency. Like all the villages I of Wonosobo District have been very open, not only is this openness also bordered by good management by the village government in Wonosobo District through a Village Partner Application.

The Village Partner Application aims to manage Village Resources and Rural Areas, Administration and Public Service Management. This application was developed to improve clean and better public services and to help manage village data effectively and efficiently. And one of the systems in the application is a Village financial information system tailored to the needs of the district, the system becomes a new feature in the Village Partner Application. At the end of 2016, 236 villages in Wonosobo have used the Village Partner Application in support of participatory village support system (TPK), Secretary of the village (Village Secretary), KADES (Head of Village) and also Treasurer.

In the implementation of the program, there are great opportunities and challenges faced by the village government, and it is also not easy, how to integrate all the important components in the development can be equally integrated ie government, society, the system itself. and accountability to be one tool that can be used by the government in reaching that goal. Because of high accountability, the public or community's rights in administering government can be fulfilled, among others, the right to know, the right to be informed and the right to be heard of its aspirations. Accountability ensures that all rights can be fulfilled, of course, remain with the full commitment of the government.

In carrying out and demonstrating the seriousness of the government is not only a single actor in encouraging accountability in the public sector, but from non-governmental parties also encourage public accountability continues to be improved so that the ultimate goal of the implementation of good governance can be achieved. One of the accountability at the village level on village finance, supported by government information technology at the village level has been facilitated by the application of a special design to facilitate village-level government in disseminating information and public services. Village Partner Application developed by Infest Yogyakarta which is the Institute of Education Studies, Social, Religion, and Culture which work independently to improve the quality of Indonesian society.

The implementation of good governance lies in how far the collaboration and synergy between the three pillars of the state, the people, government, and entrepreneurs are cohesive, harmonious, and balanced. Therefore, the accountability of the public bureaucracy will be a crucial point for the direction of democratic development in Indonesia in the present time [2]. Public accountability believed to be the key to the successful implementation of a clean and authoritative government. Accountability is one tool that can be used for public trust to grow, so it can increase community participation in every aspect of government, especially development, not only physical development but also better human resource development. However, in carrying out accountability, the public apparatus must also know how to make it work in accordance with expectations, including the public apparatus must understand and accept the responsibility to carry out its duties successfully as a responsibility and commitment of political leaders.

In principle, village information should be open and accessible to the public or the public, from planning, budgeting, administration, to reporting. Openness encourages community participation. With the participation of the community means the existence of village financial accountability in an orderly and budgetary discipline. This application also aims to maintain 
consistency, ranging from RPJM Desa, RKP Desa, APB Desa until to the budget realization report. All existing village data in the Application has been integrated with the district government so that the process of evaluation of village financial documents by the District is much more effective and efficient. So that integrated data can also be a reference work both District and District in determining the work plan in the coming year. This paper aims to try to describe, review and present data on the accountability of village finances in Wonosobo regency.

\section{A. Accountability}

First, Ghartey [3] states that accountability is aimed at obtaining answers to statements relating to what services, by whom, to whom, whom, and what. Questions that require answers include what should be accounted for, why accountability should be submitted, to whom responsibility is left, who is responsible for various parts of the community's activities, whether accountability goes hand in hand with authority, and so on.

A key purpose of corporate accountability mechanisms is to hold managers of organizations accountable for the social, environmental and economic outcomes (or impacts) arising from the actions (policies, practices and activities) of their organisations. Recent years have witnessed an explosion in such corporate accountability initiatives as part of a rapid spread of corporate social responsibility programmes [4]. Carino in [5] states Accountability is an evolution of activities undertaken by an officer either still on the path of authority or already out of his responsibility and authority. Thus each individual must really realize that every action does not only influence himself but will bring a small impact on others. So paying attention to the environment becomes absolute in every act and behavior of a government official.

Based on the above understanding, therefore the authors conclude that, in essence, accountability is the embodiment of a person's obligations or organizational units to account for the management and control of resources and implementation of policies entrusted to him in the context of achieving the goals set.

\section{B. Dimensions of Accountability}

Accountability made in the public sector consists of various dimensions. Ellwood, 1993 [6] sets out the following four dimensions of public accountability:

- Accountability honesty and law, Accountability honesty relates to the avoidance of abuse of authority, while legal accountability relates to the guarantee of compliance with other laws and regulations required in the use of public resources.

- Policy accountability relates to the issue of accountability.

- Program Accountability, Accountability program is related to the problem of achieving the objectives (effectiveness) and considering alternative programs that provide optimal results with minimal cost. The accountability of the program relates to individual units and bureaucrats conducting joint activities to achieve program effectiveness.

- Accountability Process, The accountability process is related to the problem of procedures used in the task. Has it met the adequacy of accounting information systems, management information systems, and administrative procedures Accountability processes are manifested through the delivery of fast, responsive, and inexpensive public services? Process accountability relates to the methods and 
operating procedures of a system that transforms inputs into outputs. Process accountability emphasizes that some goals may not be measurable and replaced directly, but present how activities are directed toward achieving goals.

\section{Accountability Model}

Coghill and Hodge [7] argue that accountability operates through a complex network of accountabilities. These include institutions such as parliament, investigative committees, executives, political parties, courts, ombudsmen, auditors, industry regulators, governments and the media. The model of accountability under this view, called the Networking Model (complex accountability system) is the relationship between individual networks and institutions.

Denhardt [8] describes the New Public Services approach towards changing citizen orientation on how public institutions are built on integrity and responsiveness. What are the role of government in serving and empowering and the values of democracy? Democratic service demands the realization of quality service as a form of good governance. Accountability is an obligation to convey accountability or to answer and explain the performance and actions of a person or legal entity or collective leadership of an organization to a party authorized to request information or accountability.

Management of ADD itself through three stages consisting of planning, implementation, and supervision. The three-stage linkage mechanism cannot be separated from one to the other. This is because the management of ADD is expected to realize the ideals of good governance at the lowest level of government, namely the village. One aspect to consider in ADD management is the application of accountability by rulers at the village level. (Elgya 2013)

Accountability according to Mohammad et al (2004) that has 3 types namely:

- Financial accountability: Accountability that includes financial statements comprising revenue/revenue, storage, and expenditure. With the application of village partners and the existing budget system the entire responsibility includes reports such as village income or village revenue, village savings and expenses can be known young and fast, and can also be done mobile through smartphones.

- Benefit accountability: Accountability that involves the achievement of objectives that are consistent with the procedure and most important of achieving those objectives is effectiveness. With the existing integration system in the Village Partner application, the village government accountability automatically applies. In addition to being in accordance with existing procedures, the effectiveness of accountability using this application is also perceived to be quite high.

- Procedural Accountability: Accountability is related to the importance of implementation procedures taking into account ethical, morality and legal certainty. Referring to the theory of Mohammad et al the form of accountability in Wonosobo District on the management of village budgets can be said to meet these three principles. By procedural stages are done is correct. From the legal aspect other than Law No. 6 of 2014 on the management of village assets and village funds is also explained by (PERMENDAGRI) No. 1 of 2016 on asset management. The autonomy of the village also means providing the legal power of a village to take action in accordance with applicable law. 


\section{Management of Village Finance}

Institutionally, the village has been regulated in Law no. 6 the Year 2014 on the Village which became the basis of its jurisdiction. The law has been regulated on village finances, ranging from general provisions, revenue sources, Revenue and Expenditure Budget (APBDesa) and its management, to the establishment of a Village Owned Enterprise (BUMDes). These rights and obligations result in income, spending, financing, and management of Village Finance. Specifically, village financial management has been regulated by the issuance of Minister of Home Affairs Regulation (Permendagri) Number 37 the Year 2007 concerning General Guidelines of Procedures for Reporting and Accountability of Village Government Implementation.

In the Regulation of the Minister of Domestic Affairs Number 37 the Year 2007 explained that village finance is all rights and obligations in the framework of the implementation of the village government which can be assessed by money including all forms of wealth related to the rights and obligations of the village. The village's financial resources generally come from the village's original income (PAD), funds from the Government, and the proceeds from BUMDes. The implementation of local government affairs by the village government will be funded from the APBD, while the implementation of central government affairs organized by the village government is funded by the state budget.

Hasibuan [9] Management can be defined a process that involves people to determine, interpret and achieve organizational goals that have been established with the implementation of management functions of planning (planning), organizing (organizing), the preparation of personnel or staffing (staffing), direction and leadership (leading) and supervision (controlling). Similarly, in the management of state finances, the management function is realized in the state financial management cycle which consists of planning, budgeting, budget implementation/treasury, accounting, examination, and accountability. Saidi [10] states the management of state finance is part of the implementation of state government. State financial management is the overall activity of the state financial management official in accordance with its position and authority, which includes planning, implementation, monitoring, and accountability.

\section{Result and Discussion}

\section{A. Public Financial Accountability in the Village in Wonosobo District}

In a more specific assertion, accountability is the ability of public sector organizations to provide an explanation for their actions, especially those parties in the political system that have been given the authority to undertake an assessment and evaluation of such public organizations (Starling, 2008: 169). Furthermore, according to Dubnick, [11], An important issue in the management of state finances today is how to realize accountability and foster public confidence in government financial performance. Of course, that is meant in the stae finances above all budgets sourced from the State Treasury or State Budget (APBN) including the village funds.

Control of village fund management (Add) is very important for individual and group communities because, with the control of the community, the use of village budget funds can be used in accordance with the needs and needs of community development [12]. In every village in Wonosobo District itself, village financial accountability has been implemented since 2015. With the control of the community then the activities of the program financed by the village funds will control the input and process to register the output in accordance with the planning and budgeting. 
Accountability in every village in Wonosobo regency is done through a smart application that has been used in 326 villages in Wonosobo regency. The app is a Village Partner. This application can be used by the village government to improve the standard and quality of public services at the village level. In particular, the Village Partner application is a new breakthrough for villages to be able to manage administration, data and service processes easily, quickly and transparently. This application was present in 2015 and then developed continuously, which ultimately adds a feature of village finance that helps the village government to make village governance and management systems more effective, accountable and transparent.

The Village Partner application has 8 other features besides the management of participatory village financial data (Planning, Budgeting, Stewardship, and Reporting): (1) Data management and administration of villagers; (2) Management of correspondence services of village government; (3) Preparation and presentation of village profiles; (4) Presentation of poverty data at the village level; (5) Governance of population events (Birth, Death, Moving and Migration of Workers abroad); (6) Data Collection of Village Assets; (7) Presentation of Statistics, (8) Open Survey [13]. These features are expected to help the process of village governance to be better, cleaner and decision.

The structure and each village budget post are validated by the system by the village partner application, so the process of validating and evaluating village finance data becomes more effective and efficient. The data and information of each village are integrated with the central data in the District having its address at Datadesa.wonosobo.go.id. which in the end the village data center can also be a reference or tool of work for the District or District in evaluating financial documents in each village, so that people, districts, and districts can monitor every budget or budget absorption of each village. In addition to accessing these data, the community can also provide feedback and input on data presented by the center and village.

This open-ended village financial data development initiative is not something instant. It has been started since 2014 with Infest Yogyakarta. This joint initiative has been initiated since 2014, starting with the restructuring of village planning through village appreciative planning, strengthening the capacity of public information services and strengthening village finance governance. Open Data aims to encourage community participation in rural development. Because with the spirit of novelty stakeholders believe participation can improve the quality of village development and marginal community access to development. Participation space needs to be pursued, one of them, by encouraging policymakers at the village level and opening up to the community. Public access to information is an important prerequisite in the process of strengthening participation.

The Open Village concept of open village data is the preferred approach that allows villages to ensure community access to village development data. This approach is developed by combining technology and non-technology utilization. The spirit of Open Data is actually also been started from the central government since 2008 as one of the spirits of the implementation of good governance and now adoption is quite massive, almost in all public sector has applied accountability in various aspects of its service. Open data in the village of Wonosob regency involves almost all aspects of government in the District and of course also the people in Kaamatan Wonosobo. Thus, people can easily get information about development in their village. From the information obtained is expected that the community can also participate actively participate in the development of their village so the level of accountability is increasing. With the opening of all information especially about the financial 
data of the community increasingly become brave to propose the direction of development and the needs of people in villages such as physical and non-physical development and others.

Figure 1. Open financial data scheme in Wonosobo Village

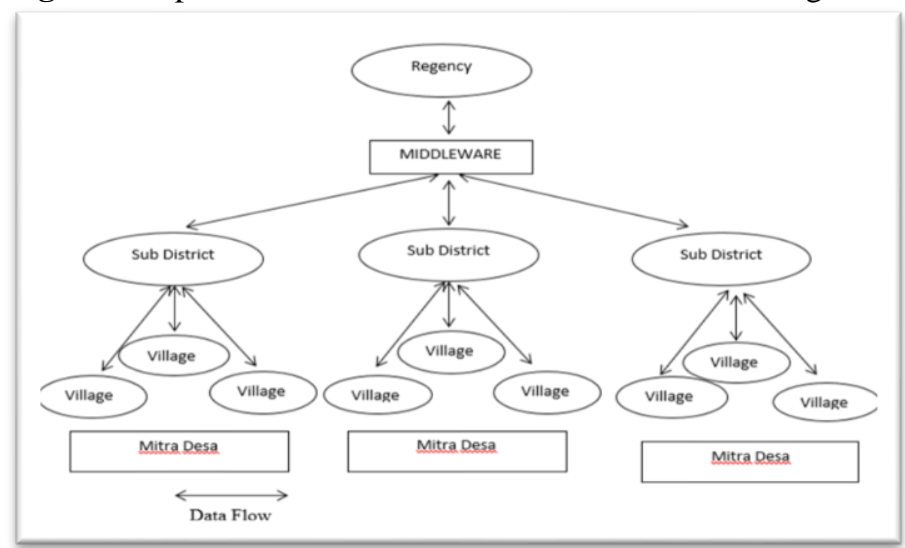

Source: Adapted from various sources.

From the picture above can be seen how the flow of information is very dynamic, financial information of each village can be seen and observed by other villages as well, on the contrary. Because in the application of the village partners there is an integration menu, thus the exchange of information every village can be young done. Which means the district government already has a commitment about the application of information disclosure system or Open data Not just data that is open and legible but also can be reprocessed and distributed in accordance with the rights and obligations of all parties (public, the government of village, the government of Regency) in guarding the village development.

\section{B. Objectives of Village Finance Accountability in Wonosobo Regency}

The increasing demands of the people towards good governance in Indonesia since the reform era have encouraged the implementation of good governance at all levels of government. The requirements for good governance are transparency in governance, participatory governance of the community, and accountability [14]. Meanwhile, according to Carlitz [15] to run every government program, accountability becomes an aspect that is always considered in running every government program. Accountability of bureaucracy in implementing programs for the benefit of society is an obligation that cannot be negotiable. This is because the community as the target group of a program always demands transparency and accountability in the process.

Disclosure of information systems and village data is also guaranteed by the law on public information disclosure No. 14 of 2008 and also reinforced by the Village Law itself that is injected in article 24 (D) which explains the principle of information disclosure in a village stating that every citizen in the village is entitled to receive correct, honest and nondiscriminatory information. Otherwise, opportunities for fraudulent practices and abuse of power will ultimately lead to corrupt practices are wide open. Because it does not check the balance or control of the community.

Therefore, the objective of Village Finance Accountability in Wonosobo Regency is to increase community participation in village development. Communities can oversee village development planning, budgeting, and accountability by actively participating in proposing 
and providing feedback in this open data enclosure. In addition, active participation will help communities understand the mechanisms and systems used by the government in managing village finances.

In the end, the community in each village feels the role and the obligation to participate in guarding the development in their respective villages. This is in line with Democratic Citizenship Theory of Denhardt and Denhard [8] which views citizens, not as entities and objects of the legal system governed and controlled by legal rights and obligations, but must place the community as active development actors to secure the rights of citizens make choices according to their interests. Democratic Citizenship can be realized in the village fund program which requires the involvement of the community from the planning of activities, from the village meeting to the village meeting, will give a sense of belonging to every villager, and will make the community life becomes important and accountable public institutions [16]. Enter civic enjoyment, accountability goes well if there are comment fields and two-way communication.

\section{Village Accountability Accountability Through Village Partner Application}

According to Ansori (2017), the obstacles to the implementation of the principles of accountability and transparency are still central to the existing authority, then the lack of understanding of village government apparatus, village policy is still formulated by some people only. Not all obstacles to e-government development come from within government organizations. In the wider community, there is a rejection of the use of the Internet in general and the government's offerings on the Internet in particular. What commentators comment on as a 'triple-A' vision of the Internet - affordability, access, and anonymity [17]. According to Nam and Pardo [18], there are three important factors in implementing a smart ICT-based system in the middle of the society that is: Institutional Factor, Technological Factor, Human factor. The government factor or in this case the village government throughout Regency of Wonosobo also has its own obstacles, because to run and use all existing instruments in the application need resources that have the ability. Or in other words, human resource is a factor that very influences performance and accountability.

Some interesting things that the findings of the research are that people generally do not expect incentives in the development process and community empowerment and most people are willing to sacrifice some of their property for the common good. However, there are still many people who have not been able to participate well due to several factors. among others:

- The problem of busyness in his work.

- The community lacks initiative in the participation process because of the capacity of the community itself such as low level of education, technical skills related to the program activities undertaken, and also related to the information problem.

- The community is also poorly organized in participation seen from the lack of a community who knows the methods and techniques of participation.

- $\quad$ Lack of participation of Kepatihan villagers in village development program

\section{Conclusion}

In the application of new things in the system of government, there will always be pro and contra as well as rejection from the public, just like what Alvin Toffler cites Shock Culture. Where a society previously comfortable with the circumstances already and forced to switch to different circumstances, even though the situation offered is much better there is still a 
concern because there is no guarantee of it. The same thing also happens when the first discourse of open data and the call to move the system from the beginning to digital. Many communities and rural governments think that this will be difficult to run.

It took quite a long time to familiarize all levels of society involved in the management of open data is accustomed to including Wonosobo regency. But it turns out that only about 6 months time required for village governance can understand and use the system, even some villages can marathon follow the existing program. Many benefits have been felt by the public using the use of budget-based applications. As the APB Desa process becomes more Effective and Efficient. In addition, the process of disbursement of funds transfers much faster. No more miscalculation of the budget, and of course also can save paper and village financial documents can be accessed and analyzed by the public.

\section{Acknowledgment}

We thank all of the people involved and contribute to this research, related institutions, Muhammadiyah University of Yogyakarta. All Wonosobo District Government officials. Villages in Wonosobo district and village government.

\section{References}

[1] "https://datadesa.wonosobokab.go.id." .

[2] W. Kumorotomo, M. Darwin, and F. Faturochman, "The implementation of slum and squatter improvement programs in the river basins of Yogyakarta," Populasi, vol. 6, 1995.

[3] J. Ghartey, Crisis, Accountability and Development in the Third World. London: Avebury, 1987.

[4] C. Deegan, M. Rankin, and J. Tobin, "An examination of the corporate social and environmental disclosures of BHP from 1983-1997: a test of legitimacy theory," Accounting, Audit. Account. J., vol. 15, no. 3, pp. 312-43, 2002.

[5] Adisasmita and Raharjo, Manajemen pemerintah daerah. Graha ilmu, 2011.

[6] S. Ellwood, "Parish and town Councils: Financial Accountability and management," Local Gov. Stud. dalam Mardiasmo, 2002,2004,2009, Akunt. Sekt. publik, Andi yogyakarta., vol. 19, pp. 368-386, 1993.

[7] C. Ken, “'Best Practice in Accountability', (Paper presented at Pnvansat1on and Good Governance Conference, Parliament House, Melbourne., in Hodge,graeme,2004 'Accountability in the Privatised State:The changing of the guardians,"' Altern. Law J., vol. 4, 2004.

[8] R. . Denhardt, J.V., and Denhardt, The New Public Service: Serving, Not Steering. New York: M.E. Sharpe, 2003.

[9] H. Malayu, Manajemen Dasar, Pengertian dan Masalah. Jakarta: Bumi Aksara, 2016.

[10] M. Saidi, djafar, Hukum Keuangan Negara, 4th ed. Jakarta: Rajagrafindo persada, 2014.

[11] M. J. Dubnick, "Accountability and Ethics: Reconsidering The Relationships," Int. J. Organ. Theory Behav., vol. 6, no. 3, pp. 405-441, 2003.

[12] S. Syamsi, "Partisipasi Masyarakat Dalam Mengontrol Penggunaan Anggaran Dana Desa," Fak. Ilmu Sos. dan Ilmu Polit., vol. 3, no. 1, 2015.

[13] "https://sekolahdesa.or.id." . 
[14] Waluyo, Manajemen Publik (Konsep, Aplikasi, dan Implementasinya dalam Pelaksanaan Otonomi Daerah). Bandung: CV. Mandar Maju, 2007.

[15] R. Carlitz, "Improving Transparency and Accountability in the Budget Process: An Assessment of Recent Initiatives," Dev. Policy Rev., vol. 31, no. 51, pp. 549-567, 2013.

[16] N. Roberts, "Public Deliberation in an Age of Direct Citizen Participation," Am. Rev. Public Adm., vol. 34, no. 4, pp. 315-353, 2004.

[17] R. Spears, T. Postmes, A. Wolbert, M. Lea, and P. Rogers, Social Psychological Influence of ICT's on Society and their Policy Implications. Amsterdam: Infrodrome, 2000.

[18] T. Nam and T. A. Pardo, "Conceptualizing smart city with dimensions of technology, people, an institutions," in Proceedings of the 12th annual international digital government research conference: digital government innovation in challengi, 2011. 